\title{
УПРАВЛІННЯ ПІДПРИЄМСТВОМ
}

UDK 621.316

O. P. Kosenko, Doctor of Economic Sciences, Professor,

T. O. Kobielieva, Candidate of Economic Sciences, Associate Professor,

N. P. Tkachova, Candidate of Economic Sciences, Associate Professor

\section{THE DEFINITION OF INDUSTRY PARK ELECTRICAL PRODUCTS}

The relevance of the research topic. Assessment and analysis of the Park of technological equipment is the basis for the development of the programme of action of each enterprise in the market for its products; it identifies the place and role of the enterprise in the economic system of society

Statement of the problem. The method of calculation of certain types of needs (e.g. the needs of the repair and maintenance of equipment) requires, as a mandatory stage of the calculation, the definition of a Park installed at the consumers.

Analysis of recent researches and publications. Problems of definition of old machinery was considered by such scientists as Voronovsky G. K. [8], Gladenko I. V. [9], Kozicki D. [10], Pererva P. G. [11-12], Pogorelov N. I.[13], Savenkova O. N. [14], Tkachov M. M. [15], Tovazhnyanskiy V. L. [16].

Unsolved problems. Businesses and industries quantitation Park electrical products is not conducted as to determine it by direct counting almost impossible.

Statement of the problem. The aim of the article is development of methodical provisions of the definition of industry Park electrical products that do not have independent technological purposes.

The main results of the study. To determine industry Park electrical automation is proposed by studying their applicability (actual presence) in any one kind of the main process equipment industry Park which is known in advance or can be set in a scientific and proven methods. In particular, while defining industry Park low-voltage equipment as a basis we can take the main types of the main technological equipment, asynchronous motors with power up to $100 \mathrm{~kW}$, the amount of generated or consumed in the sector of electricity, etc. the analysis of the coefficients of applicability of electrical equipment on different groups of cutting equipment is allowed to draw a conclusion about the different level of automation.

Conclusions. Suggested in the article the technique of definition of industry Park electrical products is universal. After some modifications it can be used to determine the Park of any products that are components element of more complex technological equipment.
УДК 621.316

А. П. Косенко, д. э. н., профресcop,

Т. А. Кобелева, к. э. н., доцент,

Н. П. Ткачева, к. э. н., доцент

\section{ОПРЕДЕЛЕНИЕ ОТРАСЛЕВОГО ПАРКА ЭЛЕКТРОТЕХНИЧЕСКИХ ИЗДЕЛИЙ}

Актуальность темы исследования. Оценка и анализ парка технологического оборудования является основой для разработки программы действий каждого предприятия на рынке своей продукции; он определяет место и роль предприятия в экономической системе общества

Постановка проблемы. Методика расчетов некоторых видов потребностей (например, на нужды ремонта и эксплуатации оборудования) предполагает, в качестве обязательного этапа расчета, определение парка установленного у потребителей оборудования.

Анализ последних исследований и публикаций. Проблемы определения парка технологического оборудования рассматривали такие ученые, как Вороновский Г. К. [8], Гладенко И. В. [9], Кочиски Д. [10], Перерва П. Г. [11-12], Погорелов Н. И.[13], Савенкова О. Н. [14], Ткачов М. М. [15], Товажнянский В. Л. [16] и др.

Нерешенные проблемы. На предприятиях $u$ e отраслях промышленности количественный учет парка электротехнических изделий не ведется, поскольку определить его методом прямого счета практически невозможно.

Постановка задачи. Целью статьи является разработка методических положений определения отраслевого парка электротехнических изделий, не имеющих самостоятельного технологического назначения.

Основные результаты исследования. Определять отраслевой парк электротехнических средств автоматизации предлагается путем исследования ux применяемости (фрактического наличии) на каком-то одном виде основного технологического оборудования, отраслевой парк которого заранее известен или может быть установлен $c$ помощью научно обоснованных и проверенных практикой методов. В частности, при определении отраслевого парка низковольтной аппаратуры за основу можно принять главные виды основного технологического оборудования, асинхронные двигатели мощностью до $100 \mathrm{kBm}$, количество вырабатываемой или потребляемой в данной отрасли электроэнергии u т.д. Анализ полученных коэфрфициентов применяемости электротехнических изделий на различных группах металлорежущего оборудования позволил сделать вывод о различном уровне их автоматизации.

Выводы. Предложенная в статье методика определения отраслевого парка электротехнических изделий является универсальной. После некоторых 


\section{УПРАВЛІННЯ ПІДПРИЕМСТВОМ}

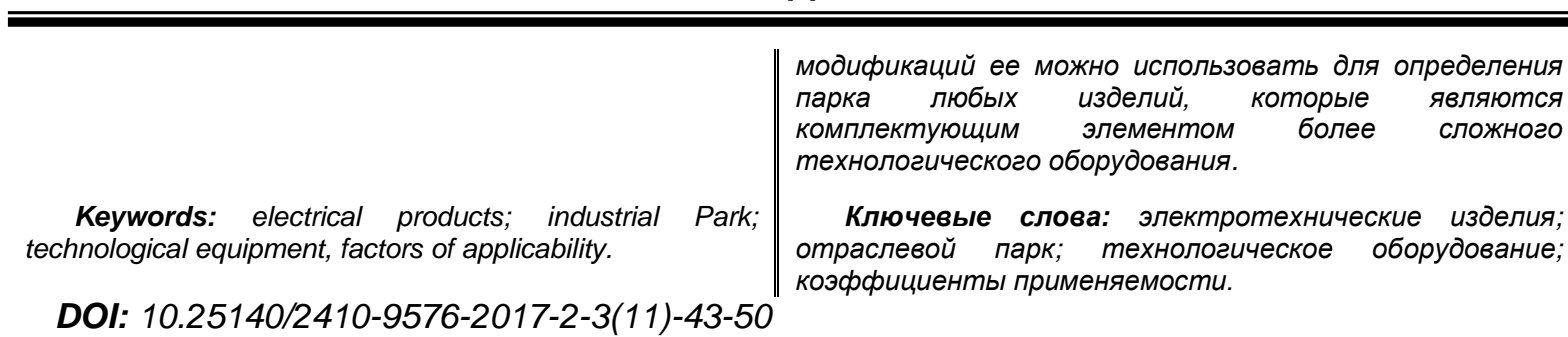

Relevance of the research topic. Enterprises of electrotechnical industry produces large volumes of products for internal and external consumption, ensuring the economy of our country as a means to accelerate scientific-technical progress, and foreign exchange earnings. For efficient production and commercial activities in the market of electrotechnical companies produce in large volumes, wide product range, each item of which requires the determination of its market characteristics: demand, supply, price, quality and the like. Market relations cover the various aspects of enterprise activity that one indicator to describe is simply impossible [1]. Therefore, in the conditions and competition to ensure stable production and cost-effective operations are very important such generalizing characteristic of the market, which is fleet of products in service [2; 3]. In the General case the value of Park products characterizes satisfied in previous periods, the demand for these products. Assessment and analysis of the Park of technological equipment and its components is a prerequisite for the formation of state economic and social policy of market regulation, the fight against inflation, the development of appropriate legislation. Fleet size of our products is the basis for the development of the programme of action of each enterprise in the market for its products; it identifies the place and role of the enterprise in the economic system of society.

Formulation of the problem. The method of calculation of certain types of needs (e.g. the needs of the repair and maintenance of equipment) requires, as a mandatory stage of the calculation, the definition of a Park installed at the consumers [4-6]. Park equipment (regional, sectoral, national) you also need to know when determining the number of staff, the calculation of the cost of its maintenance and operation, differentiation of types and models of equipment planning of its production volumes, etc. [7]. In this regard, the development of scientific and methodological foundations of determining of the Park electrical products (EP) represent an important and urgent task.

Analysis of recent research and publications. Problems of definition of old machinery was considered by such scientists as Voronovsky G. K. [8], Gladenko I. V. [9], Kozicki D. [10], Pererva P. G. [11-12], Pogorelov N. I. [13], Savenkova O. N. [14], Tkachov M. M. [15], Tovazhnyanskiy V. L. [16] etc.

However, in the works of these authors focuses on the assessment of the size of the Park the main technological equipment of machine-building enterprises. For example, in $[4 ; 10 ; 17]$ considers the problem of determining the Park of the process equipment in the chemical and light industries, the authors of works $[14 ; 16]$ were limited to the consideration of the Park only economically important equipment. However, as shown by our findings [3-7], the problem of evaluation of the Park of the main technological equipment has been largely solved, and at present this is not so important. Much more urgent and more complicated is the problem of determining the equipment fleet, which has no independent technological purpose (bearings, motors, pumps, electrical products, computers, light fixtures, measuring instruments, etc.) which the enterprises are not maintained inventory records.

Determination of unexplored aspects of the general problem. Calculations of actual equipment in operation, for certain types of industrial products have different methodological and regulatory framework. Our research suggests that for electrical products (contactors, motors, relays, fuses, switches, electromagnets, magnetic starters, transformers, etc.) such a database index is missing. Businesses and industries quantified the Park EP are not kept, because to determine it by direct counting almost impossible.

Setting an objective. The aim of the article is development of methodical provisions of the definition of industry Park electrical products that do not have independent technological purposes. Object of research are machine-building enterprises of the Kharkiv industrial region. 


\section{УПРАВЛІННЯ ПІДПРИЕМСТВОМ}

Research results. To determine industry Park electrical automation is proposed by studying their applicability (actual presence) in any one kind of technological equipment industry Park which is known in advance or can be set in a scientific and proven methods. In particular, while defining industry Park low-voltage equipment as a basis we can take the main types of the main technological equipment, asynchronous motors with power up to $100 \mathrm{~kW}$, the amount of produced or consumed energy, etc.

The determination of the direction of research depends on the sector under consideration and its characteristics. A selection of basic representative, which is determined by the ratio of applicability of EP in the industry can not be uniquely determined. It is therefore proposed to determine the coefficients of applicability is not for one product but for several, vividly characterize the manufacturing equipment industry. For example, the engineering industry, where the largest number of machine tools (metal-cutting, press-forging and foundry). Therefore, the basis of applicability of electrical equipment in the engineering industries are invited to take certain types of machine tools. This approach to defining industry Park EP, in our view, would significantly enhance the reliability and validity of the calculations.

Our recommendations for the other industries are as follows:

- for ferrous metallurgy the object of study are recommended converters, blast furnaces, openhearth furnaces, blooming, slabs;

- for chemical industry - synchronous and asynchronous electric motors;

for the timber and woodworking industry - woodworking machines, machinery, production line;

for the oil and gas industry - drilling rigs;

- for the electricity and coal industry electromagnetic control station;

- for the transportation industry, both surface and underground types of vehicles;

- for light and food industry - the amount of technological power equipment.

Based on the above hypotheses, the estimated formula industry Park of i-th type, EP has the following form:

$$
N_{i}=N_{j} \cdot K_{i j}
$$

where $N_{j}$ - industrial Park $j$-th type of equipment for which the coefficient of applicability of the $i$-th type EP $K_{i j}$.

In relation to engineering industries for certain types of the main technological equipment of formula (1) takes the following form:

$$
N_{i}=\sum_{j=1}^{J=n}\left(N_{j} \cdot K_{i j}\right)
$$

where $j$ - is the type of process equipment - metal-cutting, press-forging, foundry; $\mathrm{n}$ - number of types of the main technological equipment (in this case, $n=3$ ).

The practical calculation of coefficients $K_{i j}$. of applicability should be given special attention, as these values represent the most important components when you use these guidelines.

First made a classification of the selected object of study for a number of distinctive groups or types of products. For example, engineering industries (automotive, instrumentation, machine tools, electrical engineering, tractor construction, etc.) selected objects studies - metal-cutting machines, press-forging and foundry equipment break even on a number of close by their design and technological content of group assignments.

For each of the classification groups and sub-groups of technological equipment analysis of the Park to identify and model the most massive application. The total Park selected models in total should be quite a representative sample - not less than $70-80 \%$ of the total industry Park of technological equipment.

Calculation of the coefficients of applicability of the specific type of EP at this group classification of the main technological equipment (pieces per unit). The estimated relationship has the following form: 


\section{УПРАВЛІННЯ ПІДПРИЕМСТВОМ}

$$
K_{i j}^{s}=\frac{\sum_{n=1}^{m} K_{i j}^{s n} \cdot O_{s n}}{\sum_{n=1}^{m} O_{s n}},
$$

where $K_{i j}^{s}$ - coefficient of applicability in the $i$-th of EP for the $s$-th classification group $j$-th type of process equipment, units per unit of equipment; $O_{s n}$ - industry Park of the $n$-th model $s$-th groups of technological equipment; $K_{i j}^{s n}$ - the number of pieces of the $i$-th of EP $n$-th model $s$-th group of equipment of the $j$-th species.

The results of this phase is to determine the coefficients of applicability of certain types and types EP are the specific models of equipment. The basis for such calculations are the norm configuration electrical diagrams of the individual models in this classification groups the main technological equipment, as well as their number in the industrial Park.

Calculates the coefficients of the applicability specific to this EP unit of the $j$-th species $K_{i j}$ :

$$
K_{i j}=\sum_{s=1}^{1} K_{i j}^{s} \cdot \gamma_{j s} \text {, }
$$

where $I$ - is the number of classification groups of technological equipment of this type; $\gamma_{j s}-$ share $s$-th classification group in the industrial Park of the $j$-th type of process equipment.

According to this method were determined the coefficients of applicability of various types of EP metal-cutting, press-forging and foundry equipment, the practical application of which allows to identify EP Park for engineering industries.

As an example, given the values of the coefficients of applicability of electromagnetic actuators and limit switches of various types on separate classification groups of machine tools.

Coefficients of the applicability of different types of EP

Table 1

\begin{tabular}{|c|c|c|c|c|c|c|}
\hline \multirow[t]{2}{*}{ Type EP } & \multicolumn{5}{|c|}{ Classification groups of metal-cutting machines } & \multirow{2}{*}{$\begin{array}{l}\text { On one } \\
\text { machine }\end{array}$} \\
\hline & Lathe & Grinding & $\begin{array}{l}\text { Planing, slotting } \\
\text { and broaching }\end{array}$ & Drilling & Milling & \\
\hline \multicolumn{7}{|c|}{ Electromagnetic contactors } \\
\hline ПМЛ-000М & 0,504 & 0,630 & 0,588 & 1,346 & 0,547 & 0,706 \\
\hline ПМЛ-1000 & 1,567 & 1,740 & 0,735 & 1,135 & 1,544 & 1,220 \\
\hline ММЛ-2000 & 1,212 & 0,512 & 0,114 & 0,596 & 1,410 & 0,731 \\
\hline ПМЛ-3000 & 0,450 & 0,266 & 0,102 & 0,046 & 1,100 & 0,296 \\
\hline ПМЛ-4000 & 0,060 & 0,142 & 0,046 & 0,012 & 0,150 & 0,052 \\
\hline ПМЛ-5000 & 0,006 & 0,004 & 0,024 & - & - & 0,003 \\
\hline ПМЛ-6000 & - & - & 0,0666 & - & - & 0,002 \\
\hline \multicolumn{7}{|c|}{ The ultimate and limit switches } \\
\hline ВK-200 & 0,129 & 0,081 & 1,346 & 0,035 & 1,333 & 0,249 \\
\hline ВK-300 & 0,02 & 0,047 & - & - & - & 0,010 \\
\hline BK-400 & 0,403 & 0,072 & 0,152 & 0,187 & 0,132 & 0,174 \\
\hline ВПК-1000 & 0,441 & 0,109 & 0,009 & 0,060 & 0,110 & 0,146 \\
\hline ВПК-2000 & 1,625 & 0,228 & 0,976 & 0,183 & 1,561 & 0,654 \\
\hline ВПК-3000 & - & - & 0,058 & - & - & 0,002 \\
\hline БВК-24 & - & 0,072 & 0,095 & - & - & 0,017 \\
\hline БП-21 & - & - & - & 0,037 & 0,065 & 0,018 \\
\hline БПР-22 & - & 0,004 & - & 0,037 & 0,007 & 0,012 \\
\hline БПК-4000 & - & 0,009 & - & 0,06 & - & 0,004 \\
\hline
\end{tabular}
in a separate classification groups of metal-cutting machines 


\section{УПРАВЛІННЯ ПІДПРИЕМСТВОМ}

Calculations of the coefficients of EP applications, an example of which is given in table 1, was conducted by the authors for various types of manufacturing equipment installed at the enterprises of machine-building complex. In Tab. 2 shows a generic aggregated data on the coefficients of applicability to various types of technological equipment in the engineering industries.

Table 2

Coefficients of the applicability of various EP at the basic types of technological equipment in the sectors of mechanical engineering

\begin{tabular}{|l|c|c|c|}
\hline \multirow{2}{*}{ EP kinds of } & \multicolumn{2}{|c|}{ The coefficients of applicability of unit process equipment, st. } \\
\cline { 2 - 4 } & Cutting & Forging & Foundry \\
\hline Circuit breakers & 1,819 & 1,590 & 2,181 \\
\hline Electromagnetic contactors & 3,010 & 3,898 & 5,371 \\
\hline Control buttons & 4.353 & 5,433 & 5,278 \\
\hline Relay & 2,751 & 5,535 & 2,858 \\
\hline The end switches and travel & 2,376 & 1,620 & 3,852 \\
\hline Electromagnetic clutches and magnets & 0,875 & 2,092 & 3,044 \\
\hline Fuses & 0,931 & 0,530 & 1,974 \\
\hline Switches & 2,304 & 0,850 & 2,460 \\
\hline Transformers & 1,124 & 1,323 & 1,092 \\
\hline Light fixture & 1,320 & 1,457 & 1,365 \\
\hline Terminals & 12,343 & 26,649 & 16,672 \\
\hline The switches & 0,342 & 0,211 & 0,196 \\
\hline Thyristor contactless starters & 0,769 & 0,387 & 0,118 \\
\hline Other types of EP & 0,649 & 0,841 & 0,548 \\
\hline
\end{tabular}

However, the use of the above techniques in practice is limited by the fact that in the industrial Park j-th type of process equipment can be represented by different years of release (Tab. 3). More new equipment generally has a higher level of automation and saturation of electrical products. The change in the level of automation of the main technological equipment objectively leads to a change in the values of the coefficients of applicability. In this regard, the analysis of the Electromechanical schemes of technological equipment of one year gives an incomplete view of the actual applicability of EP for its $j$-th view.

Age structure of the fleet of technological equipment of machine-building enterprises

\begin{tabular}{|l|c|c|c|}
\hline \multirow{2}{*}{ Service life, years } & \multicolumn{2}{|c|}{ The percentage of equipment in the industrial Park, \% } \\
\cline { 2 - 4 } & Cutting & Forging & Foundry \\
\hline Up to 10 years & 32,7 & 35,0 & 31,0 \\
\hline 10-20 years & 27,5 & 26,3 & 41,2 \\
\hline More than 20 years & 39,8 & 38,7 & \\
\hline
\end{tabular}

This is due to the influence on production and scientific-technical progress and market competition. Therefore, the primary results of the calculation branch of the Park EP will have a low level of accuracy that predicts their adjustment and refinement.

It is proposed to analyze the applicability of EP models on the basis of equipment not on one sample year, and several (for example, three years of issue). All the manufacturing equipment is divided into three age groups (actual lifetime is 10 years, 10-20 years and above 20 years). A sufficiently large gap in terms of operation is attributable to the substantial deterioration of Park of the process equipment at Ukrainian machine-building enterprises (table 3). For each of the age groups of technological equipment to determine the coefficients of applicability of various types of EP.

The results of the analysis of applicability of electromagnetic actuators on different types of process equipment are listed in Tab. 4. 
УПРАВЛІННЯ ПІДПРИЕМСТВОМ

\begin{tabular}{|c|c|c|c|c|c|}
\hline \multicolumn{6}{|c|}{$\begin{array}{c}\text { Coefficients of the applicability of electromagnetic actuators for the cutting machines of } \\
\text { different years of release }\end{array}$} \\
\hline \multirow{2}{*}{$\begin{array}{l}\text { Equipment type and } \\
\text { year of issue }\end{array}$} & \multicolumn{5}{|c|}{ Electromagnetic contactors for nominal current, $\mathrm{A}$} \\
\hline & 10 & 25 & 40 & 63 & 100 \\
\hline \multicolumn{6}{|c|}{ Cutting } \\
\hline 1993 & 1,31 & 1,13 & 0,24 & 0,11 & 0,03 \\
\hline 2002 & 1,56 & 1,34 & 0,30 & 0,08 & 0,03 \\
\hline 2011 & 2,02 & 1,81 & 0,33 & 0,14 & 0,03 \\
\hline \multicolumn{6}{|c|}{ Forging } \\
\hline 1993 & 1,72 & 1,50 & 0,36 & 0,23 & 0,13 \\
\hline 2002 & 2,15 & 1,24 & 0,29 & 0,28 & 0,15 \\
\hline 2011 & 2,71 & 0,91 & 0,22 & 0,21 & 0,08 \\
\hline \multicolumn{6}{|c|}{ Foundry } \\
\hline 1993 & 0,92 & 0,94 & 0,07 & 0,02 & 0,01 \\
\hline 2002 & 1,07 & 1,09 & 0,09 & 0,02 & 0,01 \\
\hline 2011 & 1,14 & 1,31 & 0,14 & 0,03 & 0,015 \\
\hline
\end{tabular}

The feasibility of this approach, in our view, especially noticeable when defining EP Park for engineering industries with a large proportion of any age group equipment. Despite the complexity of the calculations, the accuracy of the final result in this case is increased.

Consequently, the coefficients of applicability of EP major types of process equipment can be calculated as follows:

$$
K_{i j}=\sum_{t=1}^{h} K_{i j}^{t} \cdot \beta_{j}^{t},
$$

where $K_{i j}^{t}$ - coefficient of applicability of the $i$-th type, THESE on the $j$-th type of process equipment in a given time interval $t$ the actual period of service; $\beta_{j}^{t}$ - the percentage of equipment with a given period $t$ of his service in the fleet.

The values of the coefficients of applicability, is given in table 5, was calculated based on the dependence (5).

Table 6

Coefficients of the applicability of electromagnetic actuators for metal-cutting equipment based on its age structure

\begin{tabular}{|l|c|c|c|c|c|}
\hline \multirow{2}{*}{ Type of equipment } & \multicolumn{5}{|c|}{ The coefficients of the applicability of electromagnetic starters on rated current, A } \\
\cline { 2 - 6 } & 10 & 25 & 40 & 63 & 100 \\
\hline Cutting & 1,62 & 1,42 & 0,28 & 0,11 & 0,03 \\
\hline Forging & 2,48 & 1,05 & 0,25 & 0,23 & 0,10 \\
\hline Foundry & 1,01 & 1,08 & 0,09 & 0,02 & 0,11 \\
\hline
\end{tabular}

Conclusions. The production and consumption of electrical products have a leading role in the implementation of electrification, modernization, mechanization, automation and intensification of production processes. With such a wide variety of applications of electrical products requires the development of comprehensive measures for the development of planning and forecasting of production and sales from the standpoint of real demand, which involves improvement of methods for the determination of the current and future needs for EP various needs. An important part of these calculations is the value of the Park, EP being in operation. 


\section{УПРАВЛІННЯ ПІДПРИЄМСТВОМ}

\section{References}

1. Kobyelyeva, T.O. (2011). Elektrotekhnichna haluz Ukrayiny: suchasnyy stan ta perspektyvy rozvytku [Electrical industry of Ukraine: current state and development prospects]. Visnyk NTU «KhPl» - Bulletine of NTU «KhPl», 26, 34-43 [in Ukrainian].

2. Kobeleva, T. O. (2011). Metodychni zasady monitorynhu koniunktury rynku asynkhronnykh elektrodvyhuniv [Methodical principles of monitoring of market of asynchronous electric motors]. Upravlinnia rozvytkom - Development management, 101, 258-260 [in Ukrainian].

3. Kotsysky, D., Pererva, P. G. \& Kosenko, A. P.(2010). Stratehichne upravlinnya vyrobnychym potentsialom i pidvyshchennya konkurentospromozhnosti pidpryyemstva [Strategic management of production potential and improve the competitiveness of enterprises]. Visnyk NTU «KhPI»Bulletine of NTU «KhPI», 62, 112-118. [in Ukrainian].

4. Pogorelov, M. I., Pererva, P. G., Pogorelov, S. M. et al. (2015). Upravlinnya personalom ta ekonomika pratsi [Personnel management and labor Economics]. M. I. Pogorelov, P. G. Pererva, S. M. Pogorelova, O. P. Kosenko (Eds.). Kharkov: «Shchedra sadiba plyus» [in Ukrainian].

5. Tovazhnianskyi, V. L.,

Pererva, P. G., Kobielieva, T. O. \& Tkachova, N. P. (2012). Antykryzovyi mekhanizm staloho rozvytku pidpryiemstva [Anti-crisis mechanism for sustainable enterprise development]. Kharkiv: Virovets A. P.: Apostrof [in Ukrainian].

6. Pererva, P. G. \& Kobyelyeva, T. O. (2012). Vyznachennia ryzyku otsinky stanu koniunktury vitchyznianoho rynku asynkhronnykh dvyhuniv [The definition of risk assessment of the situation of the domestic market asynchronous motors]. Marketynh $i$ menedzhment innovatsii - Marketing and Management Innovation, 1, 7988 [in Ukrainian].

7. Kosenko, O. P., Kobyelyeva, T. O. \& Pererva, P. G. (2014). Koniunktura tekhnolohichnoho rynku: otsinka ryzykiv komertsializatsii obiektiv intelektualnoi vlasnosti [Technological market conditions: assessment of the risks of commercialization of intellectual property objects]. Visnyk NTU «KhPl» - Bulletine of NTU «KhPl», 1076, 76 - 87 [in Ukrainian].

8. Pererva, P. G., Tkachev, M. M. \& Kobielieva, T. O. (2016). Ekonomika i upravlenie innovatsionnoi deiatelnostiu [Economics and management of innovation activities]. Naukoviy visnik Polissya - Scientific bulletin of Polissya, 8 (2), 240-246 [in English].

9. Gladenko, I. V. \& Pererva, P. G. (2010). Monltoring innovatsiynoyi diyalnosti: interpretatsiya rezultativ [Monitoring of innovative activity: interpretation of results]. Marketing i menedzhment innovatsiy - Marketing and innovation management, 2, 108-116 [in Ukrainian].

10. Pererva, P. G., Voronovskii, G.K., Pogorelov, N. I. et al. (2009). Ekonomika $i$ upravleniye innovatsionnoy deyatelnostyu [Economics and management of innovation]. Kharkiv: NTU «KhPl» [in Ukrainian].

11. Pererva, P. G. \& Savenkova, O. N. (2002). Analiz finansovogo sostoyaniya predpriyatiya [Financial analysis of the enterprise]. Visnyk NTU «KhPl» - Bulletine of NTU «KhPl», 11 (2), 118-121 [in Ukrainian].

12. Pererva, P. G. (1991). Issledovanie rynka promyshlennoi produktsii [Market research of industrial products]. Moscow: NPO «Reklama, informatsiya, marketing» [in Russian].

\section{Література}

1. Кобєлєва, Т. О. Електротехнічна галузь України: сучасний стан та перспективи розвитку / Т. О. Кобєлєва // Вісник НТУ «ХПІ». -2011. - № 26. - С. 34-43.

2. Кобєлєва, Т. О. Методичні засади моніторингу кон'юнктури ринку асинхронних електродвигунів / T. О. Кобєлєва // Управління розвитком: зб. наук. праць. 2011. - № 4 (101). - С. 258 - 260

3. Коциски, Д. Стратегічне управління виробничим потенціалом і підвищення конкурентоспроможності підприємства / Д. Коциски, П. Г. Перерва, А. П. Косенко // Вісник Національного технічного університету «ХПІ». - 2010. - Вип. 62. - С. $112-118$.

4. Погорелов, М.ІІ. Управління персоналом та економіка праці: навчальний посібник / за ред. проф. М. І. Погорелова, проф. П.Г. Перерви, доц. С. М. Погорєлова, доц. О. П. Косенко. - Х. : «Щедра садиба плюс», 2015.- 521c.

5. Антикризовий механізм сталого розвитку підприємства: монографрія / В.Л. Товажнянський, П.Г.Перерва, Л. Л. Товажнянський, І. В. Гладенко, Т. О. Кобєлєва, Н. П. Ткачова; за ред. проф. П. Г. Перерви та проф. Л. Л. Товажнянського. - Х. : Віровець А. П.: Апостроф, 2012 - 704 с.

6. Перерва, П. Г. Визначення ризику оцінки стану кон'юнктури вітчизняного ринку асинхронних двигунів / П. Г. Перерва, Т. О. Кобєлєва // Маркетинг і менеджмент інновацій. - 2012. - № 1. - С. 79-88.

7. Косенко, О. П. Кон'юнктура технологічного ринку: оцінка ризиків комерціалізації об'єктів інтелектуальної власності / О. П. Косенко, Т. О. Кобєлєва, П. Г. Перерва // Вісник НТУ «ХПІ». - 2014. №33 (1076). - C. 76 - 87.

8. Pererva, P. G. Evaluation of holder profits violation of their exclusive rights / P. G. Pererva, M. M. Tkachev, T. O. Kobielieva // Науковий вісник Полісся. - 2016. - № 4 (8), ч. 2. - C. $240-246$.

9. Гладенко, І. В. Моніторинг інноваційної діяльності: інтерпретація результатів / П. Г. Перерва, І. В. Гладенко // Маркетинг і менеджмент інновацій. - 2010. №2. - C.108-116.

10. Перерва, П. Г. Экономика и управление инновационной деятельностью / под ред. проф. П. Г. Перервы, проф. Г. К. Вороновского, проф. С. А. Меховича, проф. Н. И. Погорелова. - Харьков : НТУ «ХПИ», 2009. - $1203 \mathrm{c}$.

11. Перерва, П. Г. Анализ финансового состояния предприятия / П. Г. Перерва, О.Н.Савенкова // Вісник Нац. техн. ун-ту "ХПІ" : зб. наук. пр. Темат. вип. Технічний прогрес та ефективність виробництва. -2002. - № 11-2. - C. 118-121.

12. Перерва, П. Г. Исследование рынка промышленной продукции / П. Г.Перерва. - М. : НПО «Реклама, информация, маркетинг», 1991.- 96 с.

13. Перерва, П. Г. Практический маркетинг / П. Г. Перерва // Справочник менеджера промышленного предприятия.- М. : НПО «Реклама, информация, маркетинг», 1991. - Выпуск 1. Термины и определения. $96 \mathrm{c}$.

14. Перерва, П. Г. Маркетинг на промышленном предприятии. - М. : НПО «Реклама, информация, маркетинг», 1991. - 80 с.

15. Перерва, П. Г. Управление ассортиментом продукции / П. Г.Перерва. - М. : НПО «Реклама, 


\section{УПРАВЛІННЯ ПІДПРИЕМСТВОМ}

13. Pererva, P. G. (1991). Prakticheskiy marketing
[Practical marketing]. Spravochnik menedzhera
promyshlennogo predpriatiia - Directory of Industrial
Enterprise Manager. Moscow: NPO «Reklama, informatsiya,
marketing» [in Russian].
14. Pererva, P. G. (1991). Marketing na
promyishlennom predpriyatii [Marketing at the industrial
enterprise]. Moscow: NPO «Reklama, informatsiya,
marketing» [in Ukrainian].
15. Pererva, P. G. (1991). Upravlenie assortimentom
produktsii [Assortment management]. Moscow: NPO
«Reklama, informatsiya, marketing» [in Russian].
16. Pererva, P. G. (1991). Upravlenie sbytom
promyshlennoy produktsii $v$ sisteme marketinga [Marketing
management of industrial products in the marketing system].
Moscow: NPO «Reklama, informatsiya, marketing» [in
Russian].
17. Pererva, P. G. (2009). Trudoustroystvo bez problem
(iskusstvo samomarketinga) [Employment without problems
(The art of self-marketing)]. Kharki: Faktor [in Russian].

информация, маркетинг», 1991.- 80 с.

16. Перерва, П. Г. Управление сбытом промышленной продукции в системе маркетинга.- М.: НПО «Реклама, информация, маркетинг», 1991. - 93 с.

17. Перерва, П. Г. Трудоустройство без проблем (искусство самомаркетинга) / П. Г. Перерва. - Х. : Фактор, 2009.- 480 c.

Бібліографічний опис для цитування:

Kosenko, A. P. The definition of industry park electrical products / A. P. Kosenko, T. O. Kobielieva, N. P. Tkachova // Науковий вісник Полісся. - 2017. - № 3 (11). Ч. 2. - С. 43-50. 